Обушна Наталія Іванівна доктор наук з державного управління, доцент, професор кафедри публічного управління та публічної служби, Національна академія державного управління при Президентові України, вул. Антона Цедіка, 20, м. Київ, 03057, тел.: (068) 252-40-53, e-mail:n25obushna@gmail.com, https://orcid.org/0000-0001-5612-3104

Теплов Сергій Олександрович аспірант кафедри публічного управління та адміністрування, Інститут підготовки кадрів Державної служби зайнятості України, вул. Антона Цедіка, 20, м. Київ, 03057, тел.: (050) 919-65-33, e-mail: s-teplov@ukr.net, https://orcid.org/0000-0002-8212-1919

\title{
ЦИФРОВІЗАЦІЯ УПРАВЛІННЯ НR-ПРОЦЕСАМИ НА ДЕРЖАВНІЙ СЛУЖБІ
}

Анотація. У статті актуалізовано питання оновлення управління HRпроцесами на державній службі в контексті їх цифровізації. Розглянуто базові дефініції понятійно-категорійного апарату сфери цифрового врядування та доведено неможливість практичного застосування в одному синонімічному ряду таких дихотомічних термінів, як “цифровізація” і “оцифровування”. Встановлено, що соціальне замовлення суспільства по відношенню до сучасних державних службовців на сьогодні формується через призму цифровізації всіх сфер державної політики. 3 огляду на це, обгрунтовано об'єктивну необхідність перетворення держави на конкурентного роботодавця, здатного впроваджувати найкращі практики HR-менеджменту (у т.ч. й цифрові), які використовуються в сучасних організаціях, від бізнесу до державного сектору. Фактично це означає впровадження сучасного HR-циклу на державній службі - від рекрутингу, навчання, мотивації до оцінювання результатів, відповідальності та припинення служби. Акцентовано увагу на тому, що технологічна ера переводить HRтехнології в цифровий формат і автоматизує більшість його HR-функцій (мова йде про побудову хмарних HR-платформ 3 мобільними додатками (Human Resource Information System (HRIS) та ін.). У зв'язку з цим викладено аргументи на користь впровадження цифрових HR-практик в органах державної влади за такими напрямами: 1) упровадження єдиної інформаційної системи управління людськими ресурсами (HRMIS) у державних органах України; 2) сучасний рекрутинг; 3) професійне навчання державних службовців та розвиток навичок 
необхідних в сучасному світі. У контексті 3-го напряму 3 огляду на умови "постковідного періоду" та засади концепції Lifelong Learning, актуалізовано питання використання на державній службі такого інноваційного інструменту як дистанційне навчання (e-learning). Запропоновано шляхи успішної цифровізації управління HR-процесами на державній службі в Україні.

Ключові слова: державна служба, людські ресурси, HR-менеджмент, цифровий HR, e-learning, цифровізація, цифрове врядування.

Obushna Nataliia Ivanivna Doctor of Science in Public Administration, Associate Professor, Professor of the Department of Public Administration and Public Service, National Academy for Public Administration under the President of Ukraine, A. Tsedik St., 20, Kyiv, 03057, tel.: (068) 252-40-53, e-mail: n25obushna@gmail.com, https://orcid.org/0000-0001-5612-3104

Teplov Serhii Alexandrovich $\mathrm{Ph}$. D candidate of the Department of Public Administration, Institute of Personnel Training of the State Employment Service of Ukraine, A. Tsedik St., 20, Kyiv, 03057, tel.: (050) 919-65-33, e-mail: s-teplov@ukr.net, https://orcid.org/0000-0002-8212-1919

\section{DIGITALIZATION OF HR-PROCESS MANAGEMENT IN CIVIL SERVICE}

Abstract. The article actualizes the issue of updating the management of HRprocesses in the civil service in the context of their digitalization. The basic definitions of the conceptual and categorical apparatus of the sphere of digital governance are considered and the impossibility of practical application in one synonymous series of such dichotomous terms as "digitalization" and "digitization" is proved. It is established that the social order of society in relation to modern civil servants today is formed through the prism of digitalization of all spheres of public policy. With this in mind, the objective need to transform the state into a competitive employer capable of implementing the best practices of HR management (including digital) used in modern organizations, from business to the public sector, is justified. In fact, this means the introduction of a modern HR cycle in the civil service - from recruitment, training, motivation to performance evaluation, responsibility and termination of service. Emphasis is placed on the fact that the technological era translates HR-technologies into digital format and automates most of its HR-functions (it is about building cloud HRplatforms with mobile applications (Human Resource Information System (HRIS), etc.). In this regard, the arguments in favor of the introduction of digital HR-practices in public authorities in the following areas: 1) the introduction of a single information 
system for human resource management (HRMIS) in public authorities of Ukraine; 2) modern recruitment; 3 ) professional training of civil servants and development of skills needed in the modern world. In the context of the 3rd direction, taking into account the conditions of the the principles of the Lifelong Learning concept, the issue of using such an innovative tool as distance learning (e-learning) in the civil service is topical. The ways of successful digitalization of HR-process management in the civil service in Ukraine are offered

Keywords: civil service, human resources, HR-management, digital HR, elearning, digitalization, digital governance.

Постановка проблеми. Реформа державного управління є однією з основних реформ в Україні, що має визначальний вплив на рівень конкурентоспроможності держави та виступає важливою передумовою іiі євроінтеграційного курсу. У свою чергу, важливим “фокусом" реформи державного управління $є$ “створення спроможної, стійкої, професійної та незалежної вітчизняної державної служби, сучасних процедур для ухвалення й виконання ефективних рішень, іміджу державної служби як конкурентного роботодавця, привабливого для мотивованих i компетентних фахівців, створення якісних державних послуг для громадян та бізнесу, формування зважених і прорахованих державних політик" [1, с. 24].

На наше переконання, в епоху 4.0 індустріальної революції державна служба має відповідати не лише європейським стандартам i принципам належного врядування, а й новим вимогам ери сучасних цифрових технологій, що передбачають активну цифровізацію/діджиталізацію державних послуг, реінжиніринг процесів в органах державної влади, автоматизацію алгоритмів ухвалення рішень та ін.

У даному контексті доречно нагадати, що в умовах нових суспільних викликів важливим проявом цифровізації на державній службі вважається людиноцентризм. Відповідно сучасні цифрові перетворення на державній службі, обумовлюючи появу цифрового мислення та революціонізуючи досвід державних службовців, мають кардинально змінювати традиційні HR-підходи до роботи 3 персоналом у державних органах. Все це актуалізує питання оновлення HRтехнологій державної служби в контексті їх цифровізації, що "передбачає використання соціальних мереж та цифрових платформ, аналітики великих обсягів даних, хмарних сервісів, можливостей штучного інтелекту, доповненої реальності, спеціальних мобільних додатків, що одночасно із наданням значних переваг у здійсненні HR-діяльності веде до посилення кросфункціональності фахівця, збільшує компетентністні та професійні вимоги" [2, с. 94].

Аналіз останніх досліджень і публікацій. Формування й реалізація цифрової стратегії в публічному врядуванні, його цифровізація є важливим 
напрямом як наукових досліджень, так і практичної діяльності. У зв’язку з цим зауважимо, що концептуальні засади "Ери цифрового врядування" ("Digital Era Governance" (DEG)) вперше було представлено в наукових працях П. Данлеві, Х. Маргетс, С. Бастоу, Дж. Тінклер, Л. Де Нардіс як перехід від “Нового державного управління" (New Public Management) до більш сучасного “цифрового” управління. У подальшому концепція DEG базувалася на таких складових, як: реінтеграція, “клієнто-орієнтована цінність”; цифровізація [3]. Пізніше П. Данлеві та X. Маргетс назвуть ці напрями “першою хвилею” DEG. Водночас науковці звертають увагу й на так звану “друга хвиля" DEG [4], пов’язану із застосуванням грунтовних цифрових трансформацій в управлінській cфepi.

Разом із тим, окремі теоретико-методологічні аспекти HR менеджменту, HR технологій, формування нової системи компетентностей персоналу активно досліджували такі зарубіжні науковці як: С. Ананд, Д. Белл, П. Друкер, М. Кастельс, К. Келлі, Б. Гройсберг, Д. Ульріх, С. Паркер, та ін.

Сучасна проблематика управління людськими ресурсами на державній службі висвітлюється в наукових розробках вітчизняних науковців, а саме: В. Бакуменка, Р. Войтович, Н. Гончарук, Г. Дмитренка, С. Зелінського, О. Линдюк, Л. Прудиус, О. Петроє, С. Романюка, та ін. При цьому різним питанням проблематики цифровізації сфери HR-менеджменту на державній службі присвячені праці О. Євсюкової, Т. Запорожець, О. Карпенка, В. Куйбіди, I. Лопушинського, В. Наместнік, С. Селіванова та ін.

Незважаючи на досить грунтовні напрацювання вітчизняних науковців щодо впровадження в Україні концепції “електронного урядування” на базі технологій інформатизації державного управління, проблематика цифровізації управління HR-процесами на державній службі України й досі залишається малодослідженою. Окрім того зауважимо, що дуже часто в державних органах впровадження передових HR-технологій здійснюється точково та не завжди послідовно, спостерігається значний обсяг розбіжностей щодо бачення необхідності змін серед керівництва. Все це вимагає глибокого аналізу й оцінки теоретико-практичних засад i розстановки відповідних акцентів щодо особливостей здійснення HR-менеджменту нового типу на державній службі.

Мета статті. 3 огляду на зазначене, головна ідея статті полягає в обгрунтуванні теоретико-практичних аспектів цифровізації управління HRпроцесами на державній службі України (у т.ч. й в умовах поширення пандемії COVID-19).

Виклад основного матеріалу. На сьогодні в світі відбувається “цифровий перехід" від систем і процесів індустріальної економіки й інформаційного 
суспільства до цифрової економіки ${ }^{1}$ та цифрового суспільства ${ }^{2}$, у результаті чого цифровізація та інновації перетворюються в ключовий драйвер зростання світової економіки та добробуту громадян. При цьому в розвинутих країнах світу вже починає впроваджуватися принцип цифрового пріоритету (digital by default), за якого всі сфери послуг громадського життя пронизуються цифровізацією (digitalization), що обумовлює появу нових, унікальних систем і процесів.

Нагадаємо, що термін “digital” буквально перекладається як “цифровий”, що відразу зорієнтовує у сферу цифрових технологій, де надзвичайно важливою $є$ роль інформації та їі просування.

На думку вітчизняних науковців В. Куйбіди, О. Карпенка та В. Наместнік помилково вважати ідентичним переклад таких термінів як “digitalization” та “digitization”, оскільки вони несуть різне смислове навантаження, а саме: “digitalization" - цифровізація, а “digitization" - оцифровуванням документів або технологій (процес переведення паперових документів (чи процесів, які передбачають паперову документацію) в цифровий вигляд). Цифрові технології вимагають цифрової інформації, а оцифровування - це лише процес приведення інформації до цифрового формату. Однак для цифрових трансформацій (перетворень) недостатньо лише оцифровування даних [6, с. 7].

Отже, підтримуючи вищеозвучену тезу українських науковців, вважаємо, що “digitalization” (“цифровізація”) - це, насамперед, створення нового продукту в цифровій формі. Тому ключова відмінність “digitalization” (“цифровізація”) від “digitization” (“оцифрування”) заключається в створенні нового інноваційного продукту, з новим функціоналом і новими споживчими властивостями. I, якщо “digitization" спрямоване на вдосконалення існуючих технологій i зміну управлінських процесів, то “digitalization" дозволяє отримати суттєве удосконалення діяльності та нові конкурентні переваги. Інакше кажучи, digitalization - це вже елемент Industry 4.0 (індустріальної революції), який обумовлює вдосконалення життєдіяльності людини, суспільства і держави.

Як відомо, прогрес не стоїть на місці, тому цифрові технології все більше проникають не лише в різні сфери приватного бізнесу, а й у публічну сферу. Так, ми стаємо свідками фундаментальних змін у сфері публічного управління, де застосування цифрових технологій i цифрових даних сприяє змінам/ перетворенню управлінських процесів та передбачає створення належного

\footnotetext{
${ }^{1}$ Цифрова економіка - тип економіки, де ключовими факторами виробництва є цифрові дані (числові, текстові тощо), що надають змогу істотно підвищити ефективність, продуктивність, цінність послуг та товарів, побудувати цифрове суспільство [5].

2 Цифрове суспільство - суспільство, яке інтенсивно та продуктивно використовує цифрові технології для власних потреб (самореалізація, робота, відпочинок, навчання, дозвілля кожного), а також для досягнення та реалізації спільних економічних, суспільних та громадських цілей [5]).
} 
середовища для функціонування цифрового врядування в контексті еволюційного впровадження інформаційно-комунікаційних технологій (IКТ) у діяльність органів публічної влади.

На сьогодні цифрове врядування - необхідність та виклик сучасності. У країнах Свропейського Союзу основним чинним документом 3 розвитку цифровізації діяльності органів публічної влади залишається ініціатива Європейської Комісії “Цифровий порядок денний для Європи” (Digital agenda for Europe) [7]. В Україні основні засади впровадження цифрового врядування визначено Концепцією розвитку цифрової економіки та суспільства України на 2018-2020 роки (по суті - “Цифровим порядком денним (аджендою) України”) [8], а також планом заходів щодо іiі реалізації .

Хоча, на наш погляд, вищезгадана Концепція не надала відповіді як на питання стратегічного планування цифровізації (обмежуючись загальними деклараціями і побажаннями), так і на бачення “дорожньої карти” спільних дій iз бізнесом (як найбільш зацікавленим стейкхолдером цифрових трансформацій). Зрештою термін дії цієї Концепції закінчився в 2020 році, а проекту нового стратегічного документа у цій сфері й досі не розроблено.

На думку проф. Лопушинського І.П., цифрові технології в державному секторі України - це основа його реформування та потенційний приклад для всієї країни, яким чином потрібно використовувати переваги “цифрового” світу. Синергетичний потенціал соціальних, мобільних, “хмарних” технологій, а також технологій аналізу даних та “інтернету речей” сукупно здатні привести до трансформаційних змін у державному управлінні та в цілому, тобто зробити державний сектор України ефективним, реактивним і ціннісним [9]. У даному контексті нагадаємо, що Концепція розвитку цифрової економіки та суспільства України на 2018-2020 роки також акцентує увагу на тому, що “при системному державному підході “цифрові” технології будуть значно стимулювати розвиток відкритого інформаційного суспільства як одного з істотних чинників розвитку демократії в країні, підвищення продуктивності, економічного зростання, а також підвищення якості життя громадян України” [8].

Водночас на сучасному етапі суспільного розвитку (визначальним атрибутом якого є невизначеність та турбулентність, пов'язані зі стрімким поширенням пандемії COVID-19) державне управління в Україні переживає ситуацію, коли всі його підходи все більше переміщуються в антропологічну площину. У зв’язку 3 цим HR-менеджмент перетворюється в одну 3 головних функцій державного органу та виступає тим критичним фактором, що визначає результативність та ефективність його діяльності.

Гончарук Н. та Прудиус Л. відзначають, що управління людськими ресурсами на державній службі - це здійснення всіх функцій менеджменту, 
пов’язаних із плануванням, добором, розвитком, раціональним використанням, оцінкою, мотивацією та винагородою, вдосконаленням потенціалу людських ресурсів державних органів. Управління людськими ресурсами можна розглядати і як частину стратегії державного органу, що включає цілеспрямоване комплексне забезпечення його функціонування необхідним складом персоналу, а також створення сприятливих соціально-психологічних умов для його продуктивної діяльності [10, с. 44].

3 огляду на це, доцільно нагадати, що протягом 2020 року на державній службі значна частина робочих процесів (у т.ч. й у системі навчання та підвищення кваліфікації державних службовців) дуже швидко була переведена в онлайн, що обумовило переосмислення традиційних HR-підходів до роботи 3 персоналом у державних органах, пошук і закріплення цифрових HR-практик, які б враховували потреби державних службовців та створювали умови для їх постійного самовдосконалення, самопізнання й самореалізації в умовах нових вимог i викликів. Тобто поточна криза, якій пандемія додала багато емоційних аспектів, представила унікальну можливість подолати традиційне ставлення до людини й технологій як до окремих складових і поєднати їхні можливості задля майбутньої синергії.

Отже, соціальне замовлення суспільства по відношенню до сучасних державних службовців формується через призму цифровізації усіх сфер державної політики та звучить таким чином: працівник повинен ефективно використовувати індивідуальні здібності; бути гнучким при вирішенні професійних завдань; вміти швидко адаптуватись до змін, та безперервно навчатись (Lifelong Learning).

У свою чергу, поняття цифрового HR на державній службі, як правило, об'єднує соціальні мережі, мобільні додатки, хмарні технології, доповнену реальність та $\epsilon$ новою платформою для покращення роботи як державних

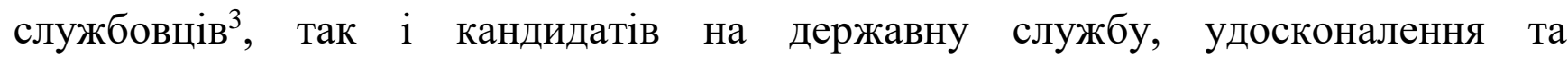
опрацювання їх досвіду. При цьому розробники цифрових технологій (інструментів цифрового робочого місця, штучного цифрового інтелекту прийняття типових управлінських рішень, blockchain-, smart-, portal-, cloud-, networkcервісів тощо) забезпечують технічну складову цифрового HR, тоді як керівництво державного органу та HR-управління повинні пропонувати свої власні інтегровані стратегіï та програми цифрового управління персоналом (табл. 1).

\footnotetext{
${ }^{3}$ Протягом десятиліть організації (у т.ч. й органи державної влади) намагалися автоматизувати такі HR-процеси, як: розрахунок заробітної плати, облік та аудит персоналу, навчання, відбір резюме, проведення співбесід, підбір та оцінка персоналу а ін.
} 
Правила HR-технологій в умовах цифрової економіки*

\begin{tabular}{|c|c|}
\hline Традиційні правила & Нові правила \\
\hline Головна орієнтація на процеси & $\begin{array}{l}\text { Орієнтація на співробітника, його } \\
\text { залученість. } \\
\begin{array}{l}\text { Продуктивність. } \\
\text { продукт/послугу }\end{array}\end{array}$ \\
\hline Фрагментарні хмарні рішення & Комплексна платформа \\
\hline $\begin{array}{l}\text { Автоматизація } \quad \text { технологічних } \\
\text { HR-процесів }\end{array}$ & $\begin{array}{l}\text { Комплексна } \quad \text { автоматизація } \\
\text { інформаційної екосистеми }\end{array}$ \\
\hline $\begin{array}{l}\text { HR-програми розроблялись для } \\
\text { команд та відділу }\end{array}$ & $\begin{array}{l}\text { HR-програми розробляються для різних } \\
\text { категорій державних службовців }\end{array}$ \\
\hline $\begin{array}{l}\text { Bсі процеси HR-технологій } \\
\text { потребують участі HR- } \\
\text { менеджера }\end{array}$ & $\begin{array}{l}\text { Частина технологій реалізована чат-ботами, } \\
\text { іншими програмними агентами і } \\
\text { самостійно } \\
\text { використовується персоналом }\end{array}$ \\
\hline $\begin{array}{l}\text { Формування та } \\
\text { баз даних }\end{array}$ & $\begin{array}{l}\text { Формування та використання динамічних } \\
\text { баз знань (у т.ч. й технологій E-learning) }\end{array}$ \\
\hline
\end{tabular}

*Джерело: узагальнено авторами з використанням [2; 11]

Безумовно, технологічна ера переводить HR-технології в цифровий формат i автоматизує більшість його HR-функцій (мова йде про побудову хмарних HRплатформ $з$ мобільними додатками (Human Resource Information System (HRIS)). I це $\epsilon$ дуже важливим, адже сучасний світ не просто швидкий, він - надшвидкий. Ми рухаємося в режимі “from slow to fast and faster". Якщо бізнес чи державна служба хочуть розвиватися, вони не можуть бути повільними.

Таким чином, сучасні реалії вимагають перетворення держави на конкурентного роботодавця, здатного впроваджувати найкращі практики HRменеджменту (у т.ч. й цифрові), що використовуються в сучасних організаціях, від бізнесу до державного сектору. Фактично це означає впровадження сучасного HR циклу на державній службі - від рекрутингу, навчання, мотивації до оцінювання результатів, відповідальності та припинення служби. Зокрема, виокремимо такі його ключові напрямки:

1) Сдина електронна система управління людськими ресурсами (Human Resource Management Information System, HRMIS). Упровадження інформаційної системи управління людськими ресурсами (HRMIS) у державних органах України здійснюється відповідно до розпоряджень КМУ від 24.06.2016 року № 474-р “Деякі питання реформування державного управління України” [12] та від 01.12.2017 p. № 844-p “Про схвалення Концепції впровадження інформаційної 
системи управління людськими ресурсами в державних органах та затвердження плану заходів щодо їі реалізації” [13]. Партнером у реалізації даного напряму $\epsilon$ Світовий банк у межах проєкту “Зміцнення управління державними ресурсами”, що фінансується ЄC за програмою EURoPAF.

$H R M I S$ - це сучасна система обліку та управління персоналом. Мета системи HRMIS полягає у забезпеченні ефективного, прозорого та надійного інструменту управління людськими ресурсами та нарахування заробітної плати в міністерствах, центральних органах виконавчої влади (ЦОВВ), обласних та районних державних адміністраціях (ОДА та РДА), інших урядових установах та державних органах через автоматизацію бізнес-процесів у сфері управління персоналом та нарахування заробітної плати. Тобто процес впровадження HRMIS передбачає, зокрема поступове впровадження державними органами підсистем “Штат і персонал” та “Зарплата і табель”, які дозволяють кожному працівнику цих державних органів використовувати підсистему “Особистий кабінет" [14, с. 19].

Подібні системи вже використовують великі приватні компанії як в Україні, так і в розвинутих країнах світу, зокрема в Японії. По своїй суті така система представляє собою аналог системи ProZorro тільки в сфері людських ресурсів на державній службі. У систему вносять усі дані про державних службовців, а саме інформацію про: структуру та штатний розпис, посади державної служби, особові справи державних службовців, нарахування і оплату праці, відпустки, кар'єрні досягнення, професійну компетентність та навчання та ін.

Функціонування HRMIS в Україні наразі здійснюється на основі Положення про інформаційну систему управління людськими ресурсами в державних органах (постанова КМУ від 28.12.2020 р. № 1343) [15].

Згідно інформації Національного агентства України 3 питань державної служби (НАДС), на кінець 2020 року в Україні 25 державних органів стали користувачами HRMIS. До HRMIS внесено інформацію щодо 16406 працівників [14, с. 19]. Впродовж 2021 року до HRMIS заплановано підключення 25\% працівників усіх державних органів [14, с. 54]. При цьому дослідна експлуатація підсистеми “Штат і персонал” відбувається у 25 державних органах, а дослідна експлуатація підсистеми “Зарплата та табель” відбувається у 5 державних органах, (3 державні органи на стадії початку дослідної експлуатації) [14, с. 19].

3 метою дотримання вимог Закону України "Про захист інформації в інформаційно-телекомунікаційних системах" у HRMIS створено комплексну систему захисту інформації (КС3I), проведено іiі державну експертизу та отримано атестат відповідності.

2. Сучасний рекрутинг. Мова йде про удосконалення конкурсів на державну службу як для кандидатів, так і для конкурсних комісій. Загалом діджиталізація 
рекрутингу передбачає використання інструментів рекрутингового маркетингу, починаючи від формування HR-бренду роботодавця, рекрутингу, навчання, мотивації до оцінювання результатів, управління ефективністю, управління змінами, відповідальності та припинення служби

Важливо відзначити, що Законом України "Про державну службу" [16] встановлюється саме компетентнісний підхід до управління персоналом державних органів, який має на меті всебічну підготовку особи не тільки як фахівця своєї справи, але i, як особистості, повноправного члена соціуму. 3 цією метою згаданим Законом [16] окреслено значні новели у процесі проходження державної служби, які зробили іiі більш проєвропейською. Наприклад, оновлення конкурсної процедури на зайняття вакантних посад державної служби є важливим досягненням України на шляху до забезпечення залучення талановитих працівників на державну службу. Хоча, сама процедура проведення конкурсу $є$ недосконалою і має низку недоліків, серед яких: високий рівень суб'єктивізму під час добору кандидатів на посади державної служби, відсутність методології визначення моделей компетенції для державних службовців, відсутність вимог до професійного складу конкурсних комісій та відсутність системи навчань їх членів, низький рівень включення до них високопрофесійних HR-менеджерів та ін.

Процес добору потенційно талановитих кандидатів із зовнішніх джерел ускладнюється також i відсутністю законодавчо врегульованої процедури активного рекрутингу (наприклад, Executive search, Headhunting, скринінг) на вакантні посади державної служби.

Водночас доцільно згадати і Центр оцінювання кандидатів на державну службу (створений на базі НАДС), де вони спочатку проходить тестування на аналітичні, вербальні та математичні здібності, а потім централізуються інші етапи конкурсу.

Крім цього, портал career.gov.uа постійно розширюється на всі вакансії в міністерствах, а потім i в інших державних органах. Окремим і складним завданням $є$ проведення інформаційних кампаній по залученню професіоналів $\mathrm{i}$ збільшенню престижу та інтересу до державної служби.

3) Професійне навчання державних службовців та розвиток навичок необхідних в сучасному світі. Така ситуація передбачає відкриття ринку навчальних послуг, що розширить можливості та швидку адаптацію навчання до реальних потреб держслужби, включаючи лідерство, інновації та сучасні підходи до прийняття управлінських рішень.

Використання в “постковідний період” сучасних IKT в освітній сфері дозволяє вирішити багато важливих проблем їі розвитку, таких як: забезпечення широкого доступу до освітніх послуг, індивідуалізація навчання, підвищення рівня варіативності і інтерактивності освітнього процесу, адекватне оновлення 
змісту освіти у відповідь на вимоги суспільства, забезпечення випереджаючого характеру освіти і, в кінцевому підсумку, підвищення ефективності навчання.

Зовсім нещодавно система дистанційного навчання (E-Learning) в державному органі вважалась інновацією, яка передбачала введення нового в мету, зміст, методи і форми прийняття управлінських рішень, організацію спільної діяльності працівників. Сьогодні, коли “навчання” й “робота” стали синонімами, дистанційне навчання забезпечує донесення державним службовцям основного обсягу навчального матеріалу, інтерактивну взаємодію з працівниками у процесі навчання, надає можливість самостійної роботи 3 навчальними матеріалами, а також у процесі навчання.

Серед найбільш популярних навчальних он-лайн ресурсів відзначимо такі:

a) Prometheus. Популярний український громадський проект масових відкритих онлайн-курсів. Головною метою проекту $\epsilon$ безкоштовне надання онлайн-доступу до курсів університетського рівня всім бажаючим, а також надання можливості публікувати та розповсюджувати такі курси провідним викладачам, університетам та компаніям;

б) EdEra. Студія онлайн-освіти EdEra створює онлайн-курси, підручники i спецпроекти. Доступ до матеріалів курсів повністю безкоштовний 3 можливістю віддячити проекту в кінці курсу;

в) ВУМ on-line. ВУМ on-line - це освітня ініціатива від Відкритого Університету Майдан, яка поширює ідеї i сприяє розвитку громадянського суспільства в Україні. Тут можна знайти навчальні курси, сформовані 3 відеолекцій, практичних завдань та контрольних запитань (для перевірки набутих знань). Це курси від провідних викладачів бізнес-шкіл, громадського сектору, практиків з бізнесу та соціальної сфери. Теми навчальних курсів пов'язані 3 : персональним розвитком та реалізацією людського потенціалу, підприємництвом, як механізмом якісного розвитку громади і суспільства, розумінням побудови та діяльності відкритого суспільства і його формування в Україні.

Загалом протягом 2020 року, згідно інформації НАДС, було розроблено та розміщено на онлайн-платформі “Спільнота практик: сталий розвиток” 3 нові навчальні ресурси, за результатами опрацювання яких учасниками згенеровано 1710 електронних сертифікатів [14].

Таким чином, можемо зробити висновок, що HR-менеджмент на державній службі в умовах цифровізації є складним і трудомістким процесом і як надалі він буде змінюватися - точно нікому невідомо. Вже сьогодні значну роль у роботі 3 персоналом відіграють соціальні мережі (LinkedIn, Facebook i Google), а поява HRMIS підвищує для HR-менеджерів швидкість збору та обробки інформації, частоту й швидкість прийняття рішень, обумовлює зростання вимог до 
технічних компетенцій таких HR-менеджерів. Окрім того з'являться нові спеціальності у галузі HR - аналітик “великих даних”, візуалізатор, оператор статистичних даних та інші.

Висновки. Резюмуючи вищевикладене, вважаємо, що для подальшої успішної цифровізації управління HR-процесами на державній службі в Україні доцільно запропонувати: 1) запровадити єдині HR-політики (ключові “правила гри”) на державній службі; 2) забезпечити трансформацію підрозділів по роботі 3 персоналом в державних органах на HR-служби, зміцнюючи їх потенціал, в першу чергу, як лідерів змін; 3) розробити стандарти для організаційної структури підрозділів управління персоналом як структурних підрозділів органів державної влади; 4) створити у структурі служб управління персоналом асесмент-центри, діяльність яких спрямовується на комплексне оцінювання персоналу (реальних здатностей і потенційних можливостей фахівців); 5) створити належні умови для професійного розвитку персоналу, а також посилити спроможність провайдерів освітніх послуг; 6) удосконалити електронний документообіг та спеціальне програмне забезпечення HR-процесів (підбір, адаптація, навчання, оцінка); 7) посилити підзвітність у системі управління персоналом через використання зручних IT-інструментів (створити нові й розвивати діючі продукти для автоматизації функції HR в державній службі; визначити IT-стратегію; масштабувати PoClick й оцифрувати процеси кадрового обліку; IT-ресурси для добору (career.gov.ua, тестовик); 8) запустити портал управління знаннями (каталог курсів)); 9) посилити кіберстійкіть державних органів (наприклад, за рахунок впровадження ключових стандартів Інтернету, включаючи IPv6 та усталені стандарти безпеки в Інтернеті, а також передові практики щодо DNS, маршрутизації та безпеки електронної пошти та ін.); 10) організовувати заходи щодо накопичення знань про цифрові технології та пов’язані 3 ними проблеми (відкриті архітектури, функції 5G - наприклад, віртуалізація, контейнеризація, слайсинг тощо), еволюцію середовища загроз, інциденти в реальному житті тощо; та ін.

На нашу думку, реалізація зазначених заходів надасть змогу створити найкращі умови для реалізації потенціалу державних службовців, підвищити їх професіоналізм, соціальну відповідальність та вмотивованість, а також ефективність HR-менеджменту на державній службі загалом.

\section{Jimepamypa:}

1. \#PARoverview - дослідження експертної думки щодо реалізації однієї з найважливіших для України реформ - реформи державного управління (Public Administration Reform). 2021. URL: http://constructive.institute/projects/paroverview? fbclid=IwAR2LI2Bbu7Thlu6L9jmhc5gyGpY6lQGXhJQKfuuMexj6YKxxdGdDkINfZQ (дата звернення 14.03.2021).

2. Бей Г.В., Середа Г.В. Трансформація HR технологій під впливом цифровізації бізнес- 
процесів. Економіка і організація управління . 2019. № 2 (34). С. 93-101.

3. Dunleavy P., Margetts H., Bastow S. \& Tinkler J. Digital Era Governance: IT Corporations, The State and E-Government. Oxford : Oxford University Press, 2006. 302 p.

4. Dunleavy, P., Margetts, H. The second wave of digital era governancece. American Political Science Association Conference, 4 September 2010, Washington DC, USA. URL: http://eprints.lse. ac.uk/27684/1/The_second_wave_of_digital_era_governance_(LSERO).pdf

5. Україна 2030Е - країна 3 розвинутою цифровою економікою. URL: https://strategy.uifuture.org/kraina-z-rozvinutoyu-cifrovoyu-ekonomikoyu.html (дата звернення 14.03.2021).

6. Куйбіда В., Карпенко О., Наместнік В. Цифрове врядування в Україні: базові дефініції понятійно-категоріального апарату. Вісник НАДУ при Президентові Украӥни (Серія “Державне управління”). 2018. №1. С. 5-10.

7. Communication from the commission to the European Parliament, the Council, the European Economic and Social Committee and the Committee of the Regions: A Digital Agenda for Europe. Brussels, 2010. URL: http://eur-lex. europa.eu/legal-content/EN/TXT/HTML/?uri= CEL EX: 52010DC0245R(01)\&from=EN.

8. Про схвалення Концепції розвитку цифрової економіки та суспільства України на 2018 2020 роки та затвердження плану заходів щодо ії реалізації: розпорядження Кабінету Міністрів України від 17 січня 2018 року № 67-p. URL : https://www.kmu.gov.ua/ua/npas/proshvalennyakoncepciyi-rozvitku-cifrovoyi-ekonomiki-ta-suspilstva-ukrayini-na-20182020-rokita- zatverdzhennyaplanu-zahodiv-shodo-yiyi-realizaciyi (дата звернення 12.03.2021).

9. Лопушинський І.П. “Цифровізація” як основа державного управління на шляху трансформації та реформування українського суспільства. Теорія та практика державного управління і місиевого самоврядування .2018. № 2. c. http://el-zbirn-du.at.ua/2018_2/20.pdf

10. Гончарук Н.Т., Прудиус Л.В. Модернізація державної служби та управління людськими ресурсами в Україні. Аспекти публічного управління. 2018. Т. 6, № 1-2. С. 42-51.

11. Куйбіда В. С., Петроє О.М., Федулова Л.І., Андрощук Г.О. Цифрові компетенції як умова формування якості людського капіталу. Аналітична записка. Київ: НАДУ, 2019.

12. Деякі питання реформування державного управління України: розпорядження Кабінету Міністрів України від 24.06.2016 p. № 474-p. URL : https://zakon.rada.gov.ua/go/4742016-\%D1\%80 (дата звернення 12.03.2021).

13. Про схвалення Концепції впровадження інформаційної системи управління людськими ресурсами в державних органах та затвердження плану заходів щодо її реалізації : Розпорядження КМУ від 1 груд. 2017 року № 844-p. URL : https://zakon.rada.gov.ua/go/844-2017$\% \mathrm{D} 1 \% 80$ (дата звернення 12.03.2021).

14. Річний звіт Національного агентства України з питань державної служби за 2020 рік. Київ: НАДС, 2021. 62 с. URL : https://nads.gov.ua/storage/app/sites/5/24.02.2021/zvit-nads-2020compressed.pdf (дата звернення 12.03.2021).

15. Положення про інформаційну систему управління людськими ресурсами в державних органах: постанова Кабінету Міністрів України від 28.12.2020 p. № 1343. URL : https://zakon.rada.gov.ua/go/1343-2020-\%D0\%BF (дата звернення 12.03.2021).

16. Про державну службу : Закон України від 10 груд. 2015 р. № 889-19 URL : http: zakon.rada.gov.ua/go/889-19 (дата звернення: 11.03.2021).

\section{References:}

1. \#PARoverview - doslidzhennia ekspertnoi dumky shchodo realizatsii odniiei $\mathrm{z}$ 
naivazhlyvishykh dlia Ukrainy reform - reformy derzhavnoho upravlinnia (Public Administration Reform) [PARoverview - a study of expert opinion on the implementation of one of the most important reforms for Ukraine - public administration reform (Public Administration Reform)]. constructive.institute. Retrieved from http://constructive.institute/ projects/ paroverview?fbclid=IwAR2LI2Bbu7Thlu6L9jmhc5g-yGpY61QGXhJQKfuuMexj6YKxxdGdD kI NfZQ [in Ukrainian].

2. Bei, H.V., \& Sereda, H.V. Transformatsiia HRtekhnolohii pid vplyvom tsyfrovizatsii biznesprotsesiv [Transformation of HR technologies under the influence of digitalization of business processes]. Ekonomika i orhanizatsiia upravlinnia - Economics and organization of management, 2 (34), 93-101 [in Ukrainian].

3. Dunleavy, P., Margetts, H., Bastow S. \& Tinkler J. (2006). Digital Era Governance: IT Corporations, The State and E-Government. Oxford : Oxford University Press, 302 p. [in USA].

4. Dunleavy, P., Margetts, H. (2010). The second wave of digital era governancece. American Political Science Association Conference, Washington DC, USA. URL: http://eprints.lse. ac.uk/27684/1/The_second_wave_of_digital_era_governance_(LSERO).pdf [in USA].

5. Ukraina 2030E - kraina z rozvynutoiu tsyfrovoiu ekonomikoiu [Ukraine 2030E is a country with a developed digital economy]. strategy.uifuture.org. Retrieved from https://strategy.uifuture.org/kraina-Z-rozvinutoyu-cifrovoyu-ekonomikoyu.html [in Ukrainian].

6. Kuibida, V., Karpenko, O., \& Namestnik, V. (2018). Tsyfrove vriaduvannia v Ukraini: bazovi definitsii poniatiino-katehorialnoho aparatu [Digital governance in Ukraine: basic definitions of the conceptual and categorical apparatus]. Visnyk NADU pry Prezydentovi Ukrainy - NAPA Bulletin under the President of Ukraine, 1,5-10 [in Ukrainian].

7. Communication from the commission to the European Parliament, the Council, the European Economic and Social Committee and the Committee of the Regions: A Digital Agenda for Europe. Brussels, 2010. URL: http://eur-lex. europa.eu/legal-content/EN/TXT/HTML/?uri= CEL EX:52010DC0245R(01)\&from=EN [in Belgium].

8. Rozporiadzhennia Kabinetu Ministriv Ukrainy Pro skhvalennia Kontseptsii rozvytku tsyfrovoi ekonomiky ta suspilstva Ukrainy na 2018- 2020 roky ta zatverdzhennia planu zakhodiv shchodo yii realizatsii vid 17 sichnia 2018 roku № 67-r [Order of the Cabinet of Ministers of Ukraine On approval of the Concept of development of the digital economy and society of Ukraine for 2018-2020 and approval of the action plan for its implementation dated January 17, 2018 № 67-r]. (2018). Retrieved from https://www.kmu.gov.ua/ua/npas/proshvalennya-koncepciyi-rozvitku-cifrovoyi-ekonomiki-ta-suspilstvaukrayini-na-20182020-rokita-zatverdzhennya-planu-zahodiv-shodo-yiyi-realizaciyi [in Ukrainian].

9. Lopushynskyi, I.P. (2018). "Tsyfrovizatsiia" yak osnova derzhavnoho upravlinnia na shliakhu transformatsii ta reformuvannia ukrainskoho suspilstva ["Digitalization" as the basis of public administration on the path of transformation and reform of Ukrainian society]. Teoriia ta praktyka derzhavnoho upravlinnia $i$ mistsevoho samovriaduvannia - Theory and practice of public administration and local self-government, 2. Retrieved from http://el-zbirn-du.at.ua/2018_2/20.pdf [in Ukrainian].

10. Honcharuk, N.T., \& Prudyus, L.V. (2018). Modernizatsiia derzhavnoi sluzhby ta upravlinnia liudskymy resursamy $\mathrm{v}$ Ukraini [Modernization of civil service and human resources management in Ukraine]. Aspekty publichnoho upravlinnia - Aspects of public administration, 1-2, $42-51$ [in Ukrainian].

11. Kuibida, V. S., Petroie, O.M., Fedulova, L.I., \& Androshchuk, H.O. Tsyfrovi kompetentsii yak umova formuvannia yakosti liudskoho kapitalu. Analitychna zapyska [Digital competences as a 
condition for the formation of the quality of human capital. Analytical note]. Kyiv: NADU [in Ukrainian].

12. Rozporiadzhennia Kabinetu Ministriv Ukrainy Deiaki pytannia reformuvannia derzhavnoho upravlinnia Ukrainy vid 24.06.2016 r. № 474-r [Order of the Cabinet of Ministers of Ukraine Some issues of public administration reform in Ukraine dated 24.06.2016 № 474-r]. (2016). Retrieved from https://zakon.rada.gov.ua/go/474-2016-\%D1\%80 [in Ukrainian].

13. Rozporiadzhennia Kabinetu Ministriv Ukrainy Pro skhvalennia Kontseptsii vprovadzhennia informatsiinoi systemy upravlinnia liudskymy resursamy $\mathrm{v}$ derzhavnykh orhanakh ta zatverdzhennia planu zakhodiv shchodo yii realizatsii vid 1 hrudnia 2017 roku № 844-r [On approval of the Concept of implementation of the information system of human resources management in state bodies and approval of the action plan for its implementation from December 1, 2017 № 844-r]. (2017). Retrieved from https://zakon.rada.gov.ua/go/844-2017-\%D1\%80 [in Ukrainian].

14. Richnyi zvit Natsionalnoho ahentstva Ukrainy z pytan derzhavnoi sluzhby za 2020 rik [Annual report of the National Agency of Ukraine for Civil Service for 2020]. Retrieved from https://nads.gov.ua/storage/app/sites/5/24.02.2021/zvit-nads-2020-compressed.pdf [in Ukrainian].

15. Postanova Kabinetu Ministriv Ukrainy Polozhennia pro informatsiinu systemu upravlinnia liudskymy resursamy $\mathrm{v}$ derzhavnykh orhanakh vid 28.12.2020 roku № 1343 [Resolution of the Cabinet of Ministers of Ukraine Regulations on the information system of human resources management in state bodies dated 28.12.2020 № 1343]. Retrieved from https://zakon.rada.gov.ua/go/1343-2020-\%D0\%BF [in Ukrainian].

16. Zakon Ukrainy Pro derzhavnu sluzhbu vid 10 hrud. 2015 roku № 889-19 [Law of Ukraine On Civil Service of December 10. 2015 № 889-19]. Retrieved from http: zakon.rada.gov.ua/go/889-19 [in Ukrainian]. 